University of Nebraska - Lincoln

DigitalCommons@University of Nebraska - Lincoln

7-1983

\title{
The Effect of Variable Spring Water Conditions on Mallard Reproduction
}

Gary Krapu

USGS Northern Prairie Wildlife Research Center, gkrapu@usgs.gov

Albert Klett

USGS Northern Prairie Wildlife Research Center

Dennis Jorde

USGS Northern Prairie Wildlife Research Center

Follow this and additional works at: https://digitalcommons.unl.edu/usgsnpwrc

Part of the Other International and Area Studies Commons

Krapu, Gary; Klett, Albert; and Jorde, Dennis, "The Effect of Variable Spring Water Conditions on Mallard Reproduction" (1983). USGS Northern Prairie Wildlife Research Center. 47.

https://digitalcommons.unl.edu/usgsnpwrc/47

This Article is brought to you for free and open access by the US Geological Survey at DigitalCommons@University of Nebraska - Lincoln. It has been accepted for inclusion in USGS Northern Prairie Wildlife Research Center by an authorized administrator of DigitalCommons@University of Nebraska - Lincoln. 


\title{
THE EFFECT OF VARIABLE SPRING WATER CONDITIONS ON MALLARD REPRODUCTION
}

\author{
Gary L. Krapu, Albert T. Klett, and DenNis G. Jorde ${ }^{1}$ \\ U.S. Fish and Wildlife Service, Northern Prairie Wildlife Research Center, \\ Jamestown, North Dakota 58401 USA
}

\begin{abstract}
Mallard (Anas platyrhynchos) breeding densities in the prairie pothole habitat of eastern North Dakota during 1961-1980 varied from 2.28 birds $/ \mathrm{km}^{2}$ in 1977 to 9.47 birds / $\mathrm{km}^{2}$ in 1963 and were correlated with pond abundance $(r=0.543, P<0.05)$. The number of basins used by pairs declined with drought, as did home-range size. Nesting activity also varied with the number of ponds holding water $/ \mathrm{km}^{2}$, ranging from high (including substantial renesting) under favorable water conditions to low during extreme drought. The span between first and last nest initiations declined by 19 days from a wet to a dry year. With severe drought conditions during spring 1977 on the Medina Study Area, pairs returned to attempt nesting but were unsuccessful, and most abandoned activity centers by mid-May. Although the average clutch size declined by about $0.7 \mathrm{egg}$ from a wet to a dry year on the Interstate Study Area, hatchability of eggs remained constant. We describe the adaptive strategy of Mallards for breeding under variable water conditions and food resources in the semiarid prairie environment of midcontinent North America. Received 26 April 1982, accepted 30 March 1983.
\end{abstract}

WATERFOWL have evolved various strategies for breeding in environments where wetland water levels are subject to extreme fluctuation. The nomadic Grey Teal (Anas gibberifrons) in Australia, for example, breeds irregularly throughout the year when flooding creates suitable habitat conditions (Frith 1967). In North America, several species of waterfowl breed sympatrically in the glaciated prairie region of the north central United States and adjoining areas of Canada (Bellrose 1980), where annual precipitation is highly variable, causing water levels in prairie wetlands to fluctuate widely from year-to-year (Weller and Spatcher 1965, Swanson and Meyer 1977). The Northern Pintail (Anas acuta), which breeds primarily in association with shallow wetlands in the glaciated prairie region (Smith 1968, Krapu 1974, Derrickson 1978), moves thousands of miles northward to the Arctic during periods of severe drought (Smith 1970, Calverly and Boag 1977, Derksen and Eldridge 1980). The Mallard (Anas platyrhynchos) is less subject than the Northern Pintail to displacement during drawdown periods (Smith 1971, Giroux 1981) but is known also to abandon nesting on the prairies under severe drought conditions (Smith 1969).

\footnotetext{
${ }^{1}$ Present address: School of Forest Resources, University of Maine, Orono, Maine 94469 USA.
}

In this paper, we examine the reproductive strategy of Mallards when breeding in the prairie pothole region. Specifically, we describe Mallard population patterns in eastern and central North Dakota during a 20-yr period and evaluate factors responsible for observed densities and reproductive effort under a broad range of wetland habitat conditions.

\section{STUdy AREA AND MethodS}

Data were collected within stratum 46, a 22,965$\mathrm{km}^{2}$ area of eastern and central North Dakota (Fig. 1) in which a segment of the annual waterfowl breeding-pair and pond survey of the U.S. Fish and Wildlife Service (USFWS) is conducted. Stratum 46 is one of 49 strata in which 3.37 million $\mathrm{km}^{2}$ of breeding habitat in Canada and the United States are sampled to estimate the breeding population of 20 species of ducks, including Mallards (Martin et al. 1979). The stratum is located principally on the Drift Plain and Missouri Coteau biotic regions, which comprise the primary Mallard breeding area in North Dakota (Stewart and Kantrud 1973, 1974). Wetland habitats are diverse, including shallow ephemeral ponds that draw down when the frost seal melts, seasonal and semipermanent wetlands, and permanent lakes (see Stewart and Kantrud 1971). The climate, geology, and hydrology of this region are described by Winters (1963), Clayton (1967), Eisenlohr and Sloan (1968), Eisenlohr (1969), and Sloan (1972). Land use is devoted principally to small grain farming and cattle ranching, the latter restricted primarily to areas of 
high relief along watercourses and in parts of the Missouri Coteau. Significant losses of natural wetland basins capable of holding water in eastern North Dakota have occurred since pristine times as a result of widespread drainage practices motivated principally by efforts to increase agricultural production. (Stewart and Kantrud 1972). Total numbers of breeding pairs and ponds in stratum 46 were obtained from USFWS aerial survey data collected along eight transects, each $29 \mathrm{~km}$ long and $403 \mathrm{~m}$ wide. The total area surveyed within the stratum was $210 \mathrm{~km}^{2}$.

Detailed studies of Mallard nesting ecology were undertaken at two sites in stratum 46 (Fig. 1): the Medina Study Area (MSA) and the Interstate Study Area (ISA). The MSA has been previously described (Dwyer 1974, Derrickson 1978). It is a $93-\mathrm{km}^{2}$ tract situated in pothole habitat of the Missouri Coteau and is devoted principally to livestock-small grain farming operations. Aerial surveys of wetland conditions (ponds holding water $/ \mathrm{km}^{2}$ ) were made during spring of 1976 and 1977 on a $52-\mathrm{km}^{2}$ segment of the MSA to supplement data from the annual pair and pond survey. Mallard nesting activity was determined by radio tracking 16 female Mallards captured by use of rocket-projected nets during 19731975 and caught in decoy traps in 1977. All were fitted with radio transmitters as described by Dwyer (1972). Beginning in early May, bird locations were determined by triangulation several times daily and plotted on base maps. Birds were monitored from ground tracking vehicles and occasionally from aircraft. Maximum Mallard home-range sizes were obtained by connecting the outermost radio-fix locations with straight lines to include all other locations (Odum and Kuenzler 1955). The "utilized territory" refers to the area receiving intensive use, as shown by plotting the distribution of radio-fix locations of individual pairs. The territory refers to a fixed area toward which both members of the pair show attachment and on which males are aggressive toward intruding females and pairs (see Titman 1983).

The ISA includes 250 ha of right-of-way along I94 in western Stutsman and eastern Kidder counties (Oetting and Cassel 1971). Intensive searches for nests on this area during 1976 and 1977 provided comparative data on levels of nesting activity and nest-initiation patterns during years of favorable and poor water conditions. The ISA was searched for nests 12 times each year at weekly intervals beginning in midApril. Most hens were flushed only once during the laying stage with this searching interval. Nest searches were conducted with a cable-chain drag (Higgins et al. 1969). Clutch size and stage of incubation were used to estimate initiation dates by backdating (Sowls 1955: 82). Stage of incubation was determined by the field candling technique described by Weller (1956). Egg hatchability was measured and is defined as the percentage of eggs that survive (to time of hatching) and produce ducklings. Nest suc-

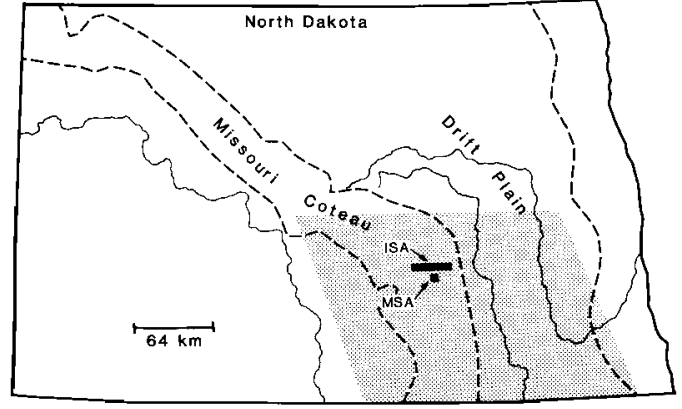

Fig. 1. Locations of study areas in south-central North Dakota. Area encompassed by stratum 46 is shaded.

cess, the number of nesting attempts that resulted in the production of at least one duckling, was estimated by a modification of Mayfield's method (Mayfield 1961, 1975) described by Klett and Johnson (1982).

\section{Results}

Mallard population trends in relation to water conditions. - The number of breeding Mallards and number of ponds holding water during May in stratum 46 showed considerable annual variation (Fig. 2). During the 20 -yr period (1961-1980), pond density ranged from 1.1 ponds $/ \mathrm{km}^{2}$ (1961) to 8.0 ponds $/ \mathrm{km}^{2}$ (1966). Pond densities fell below 3 ponds $/ \mathrm{km}^{2}$ during 5 of the $20 \mathrm{yr}(1961,1964,1973,1977$, and 1980), reflecting conditions of moderate to severe drought (Fig. 3). The density of breeding Mallards was positively correlated with pond density $(r=0.543, P<0.05)$. Mallard densities were highest in 1963 and 1966, when densities of ponds holding water were highest (Fig. 3). In 1963 record rainfall during the previous summer and fall resulted in an excellent carry-over of water in ponds, and in 1966 record snowfall produced an abundance of ponds that spring. During several years $(1967,1969,1972,1975$, and 1976), however, pair densities were low despite favorable water conditions (Fig. 3).

Effect of water conditions on pair use of wetlands (MSA).-Below-average precipitation during the summer and fall of 1976 and limited snow cover during the following winter severely reduced the abundance of temporary, seasonal, and semipermanent ponds during the 1977 nesting season. Pond densities in May declined from 10.8 wetlands $/ \mathrm{km}^{2}(1976)$ to 1.5 wetlands / 


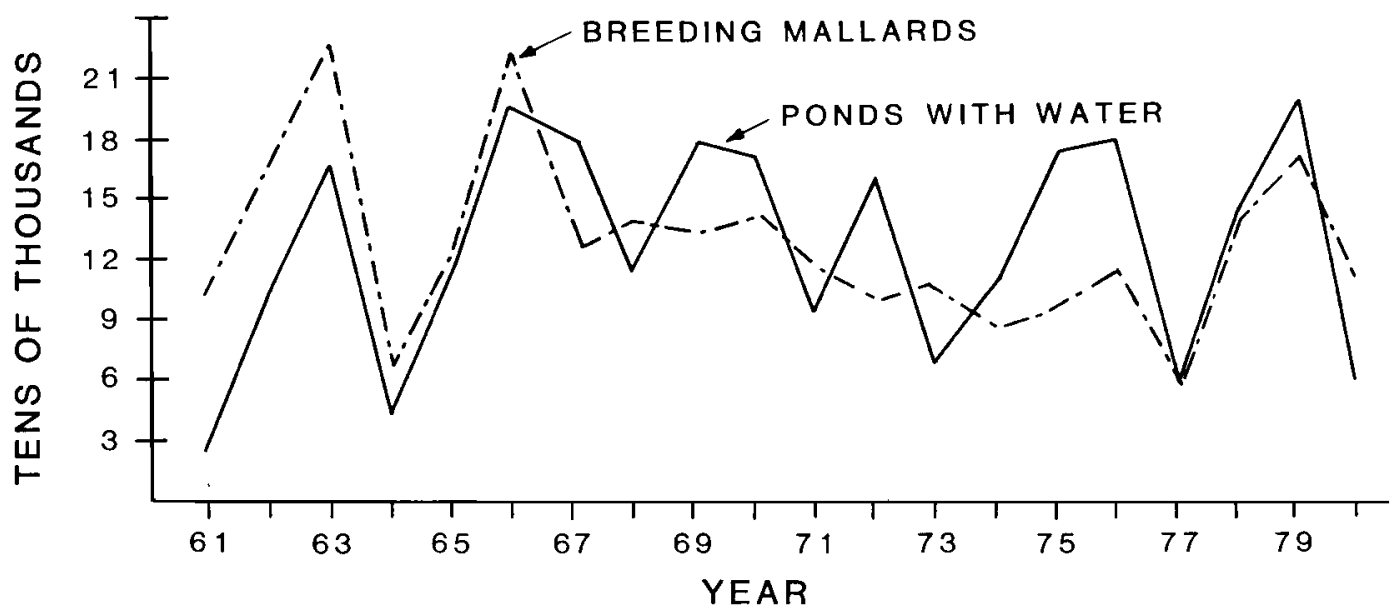

Fig. 2. Long-term trends in spring water conditions and breeding Mallard populations in eastern North Dakota (1961-1980).

$\mathrm{km}^{2}$ (1977). With the marked decline in numbers of wetlands holding water, Mallard pair densities increased from an average of 0.6 pair/ wetland in 1976 to 3.0 pairs/wetland in 1977 , concomitant with an $84 \%$ decrease in pond numbers. In 1977, pairs were restricted mostly to the large, deep, semipermanent wetlands and permanent lakes that still held water, sites that offered few suitable foraging locations.

Although breeding pairs remained on the MSA throughout the normal nesting period in 1973-1975, years when pond densities averaged $5.3,6.2$, and 7.4 wetlands $/ \mathrm{km}^{2}$, pair tenacity to breeding sites diminished markedly in 1977 as water conditions deteriorated. By midMay 1977, radio-tagged females had begun to leave the study area. The average length of stay following capture in 1977 was $38 \%$ of that of 1973-1975 (Table 1). Movement patterns of individuals that were relocated after departure suggest that birds were moving relatively short distances after abandoning the MSA. After de- parture on 26 May 1977, one female moved northward about $15 \mathrm{~km}$ and remained in the vicinity of a large marsh until 14 June. A second northward move (about $26 \mathrm{~km}$ ) was made on 15 June. Another female departed from the study area on 7 May and was relocated about $29 \mathrm{~km}$ northeast of there on 21 June.

The number of basins used by individual females decreased sharply during drought (Table 1) as pond numbers declined. The use of fewer wetlands was associated with an abbreviated stay by most pairs during the spring of 1977 . Only three radio-marked females remained for $20+$ days in 1977. Radio-tagged female Mallards occupied home ranges that overlapped those of other pairs in 1977, but utilized territories were discrete (Fig. 4). Home ranges of the four females for which sufficient data were available for 1977 averaged 246.1 ha, a $47 \%$ decline from the 467.8-ha average home-range size recorded during 1973-1975.

Effect of water conditions on nesting activity.-

TABLE 1. Reproductive characteristics of radio-tagged female Mallards during years of average water conditions and year of severe drought on the Medina Study Area in south-central North Dakota.

\begin{tabular}{lcc}
\hline \hline & Wetland status \\
& Normal & Dry \\
& $1973-1975$ & 1977 \\
$(n=8)$ & $(n=8)$ \\
\hline Length of stay (days) $^{a}$ & $43.5 \pm 16.5$ & $16.4 \pm 12.1$ \\
Number of wetlands used $^{a}$ & $15.5 \pm 6.0$ & $9.0 \pm 4.0$ \\
Number of nesting attempts & 14 & 1 \\
\hline
\end{tabular}

Mean \pm SD. 


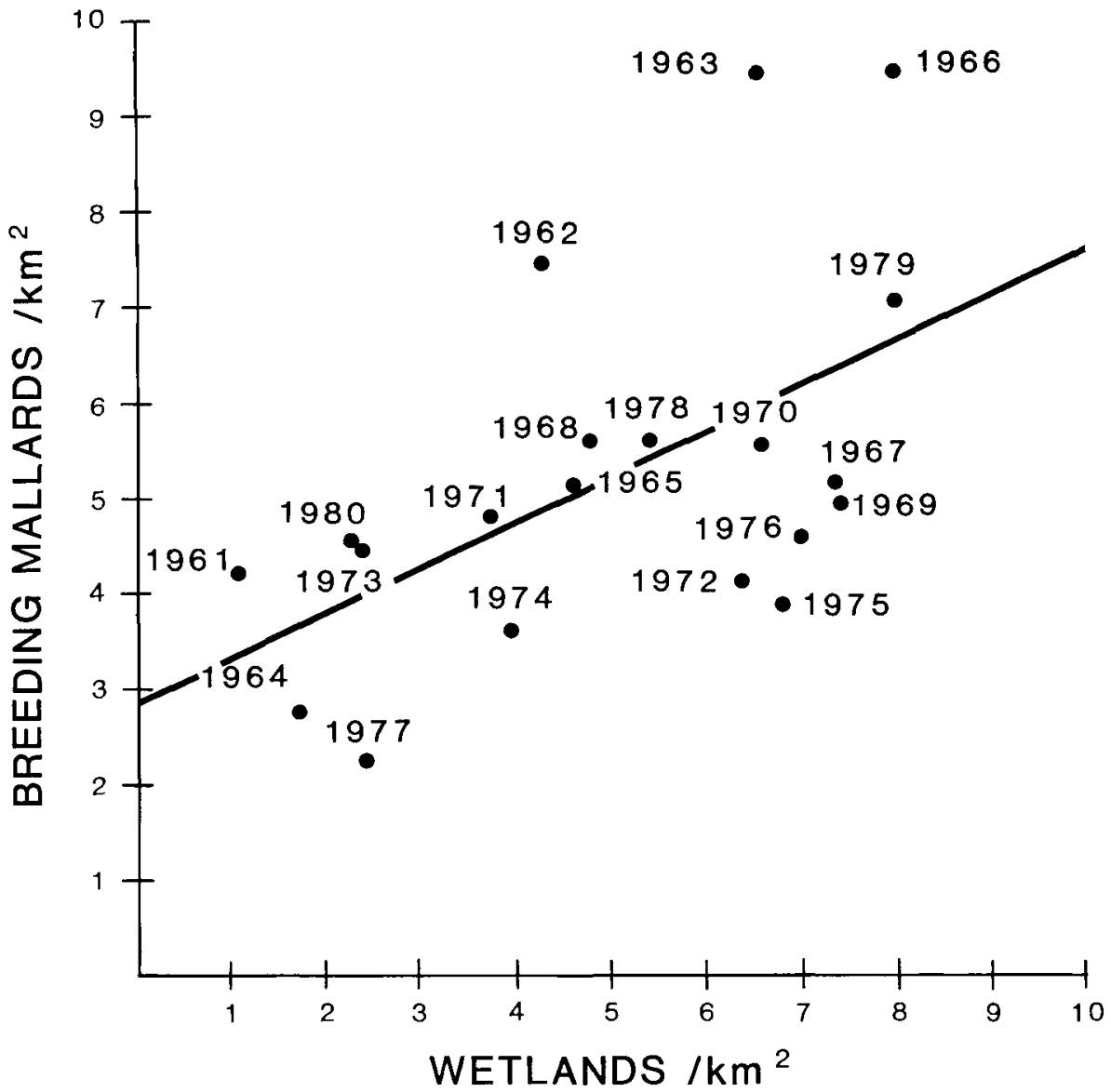

Fig. 3. Relationship between estimated densities of ponds holding water and densities of breeding Mallards in eastern North Dakota (1961-1980).

The number of nests initiated by Mallards varied with water conditions. During drought in 1977 , nesting activity diminished from a moderate to low level, depending on location. On. the ISA in 1976 and 1977, the number of Mallard nests found declined $31 \%$, from 135 to 93 . Birds nested nearly 3 weeks longer in 1976. The nest initiation interval, i.e. time-span between first and last nest initiations, was 85 days in 1976 ( 6 April-29 June) and 66 days in 1977 (12 April-15 June), a decline of $22 \%$. In $1976,75 \%$ of all nest initiations occurred within a 41-day interval (16 April-26 May), compared with a 29-day period (17 April-15 May) during 1977 (Fig. 5). Patterns of nesting activity differed between years: in 1977, the pattern was more clearly unimodal than in 1976, when extensive renesting appears to have taken place. Nesting activity began about 1 week earlier in 1976 than in 1977. The median date of nest initiation, however, was on 3 May in 1977, 6 days earlier than the previous year because of fewer renesting attempts (Fig. 5).

Radio-tagged females on the MSA averaged 1.8 nest/female during 1973-1975, when pond densities ranged from 5.3 to 7.4 wetlands $/ \mathrm{km}^{2}$. Nesting activity on the MSA nearly ceased during drought conditions in 1977, when 1.5 wetlands $/ \mathrm{km}^{2}$ held water in late May (Table 1). With only scattered, deep, semipermanent and permanent wetlands in 1977, one of the eight radio-tagged females is known to have nested.

Clutch size, hatchability, and nest success.-Mean clutch size on the ISA declined from $9.8 \pm 1.5$ eggs (87 nests) in 1976 to $9.1 \pm 1.5$ eggs (63 nests) in $1977(P<0.02)$. The slopes of the regression lines relating clutch size to date of nest initiation during 1976 and 1977 are par- 


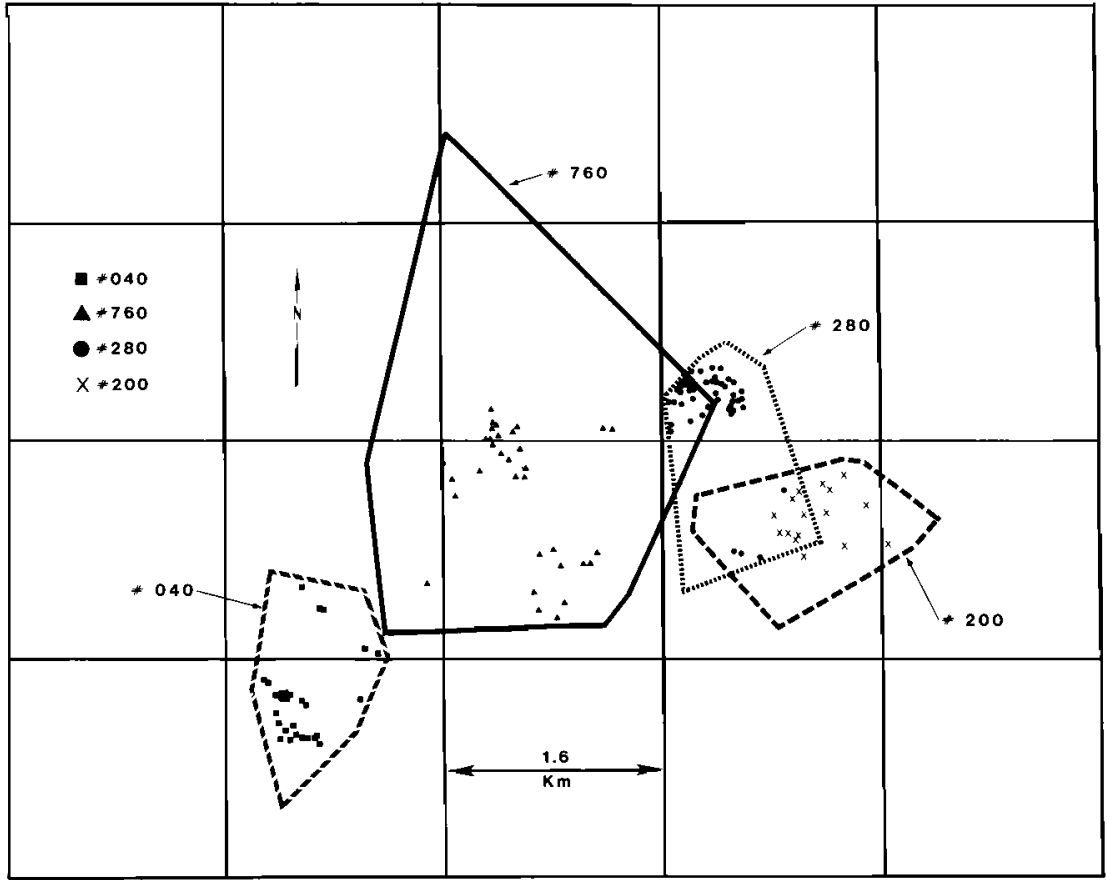

Fig. 4. Home ranges of radio-tagged, paired female Mallards on the Medina Study Area during spring, 1977. Distribution of radio-fix locations identifies utilized territories.

allel, indicating that a similar magnitude of difference in clutch sizes existed throughout the nesting season (Fig. 6). Egg hatchability rates during 1976 and 1977 were 96.9 and $97.7 \%$, respectively $(P>0.05)$.

Estimates of nest success increased from 16.7 (1976) to $41.3 \%$ (1977). This change was caused primarily by a higher loss of nests to predation during the former year.

\section{Discussion}

Our study indicates that the annual variation in the densities of Mallards occupying the prairie pothole habitat of eastern. North Dakota is correlated with the number of ponds holding water (see Crissey 1969, Dzubin 1969). The magnitude of the correlation $(r=0.543)$, however, suggests that other factors also contribute to observed annual differences in Mallard breeding densities.

Breeding-site philopatry may account for some of the variation in Mallard habitat occupancy not directly attributable to water conditions. Previous studies have shown that at least some of the yearling females return to their natal areas to breed (Sowls 1955, Lee and Kruse 1973, Sellers 1973, Doty and Lee 1974, Bailey 1979). Similarly, females that are successful in hatching a brood generally return the following year (Doty and Lee 1974). Hence, if female mortality is not excessive during the nonbreeding period of the year, local densities reflect recruitment rates as well as water conditions.

Mallards unsuccessful at nesting probably account for a high proportion of the segment of the population that relocates in response to changing water conditions. Current information suggests that, over large areas of the glaciated prairie region, recruitment rates are low due to high rates of nest loss from predation (Cowardin and Johnson 1979), and losses from predation have intensified, because habitat loss has increased the probability of contact between foraging predators and nesting waterfowl (Johnson and Sargeant 1977). The recruitment rate among upland-nesting Mallards in North Dakota on unmanaged lands has been estimated at only 0.5 (Cowardin and Johnson 1979), although there are pockets of birds that are more successful in that they nest in association with islands and other sites where pre- 


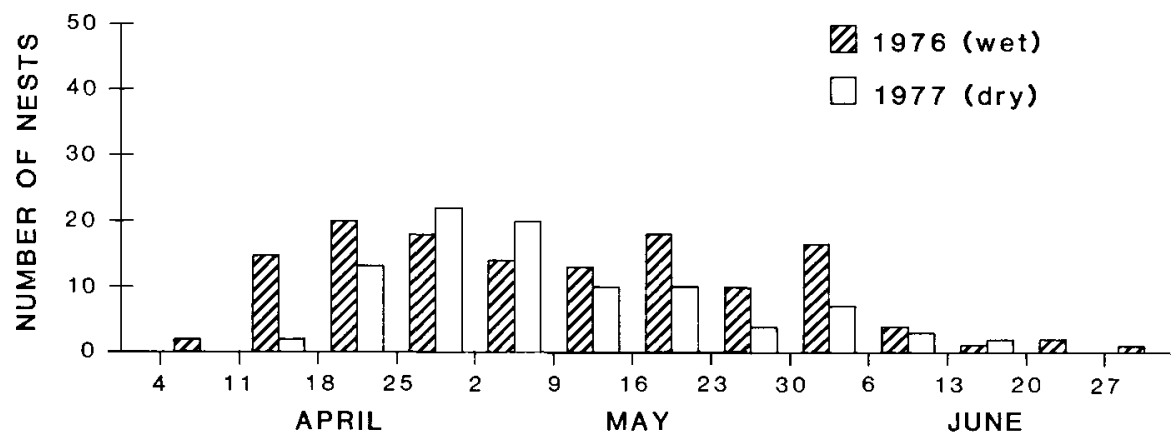

Fig. 5. Number of weekly Mallard nest initiations and annual patterns of nesting on the Interstate Study Area during 1976 and 1977.

dation is low (Drewien and Fredrickson 1970 , Giroux 1981, Duebbert et al. in press). Another factor lowering recruitment is the high loss of broods during the first 2 weeks after hatching. A recent study conducted within stratum 46 indicated that $52 \%$ of the Mallard broods were totally lost during the brood-rearing period, mostly from predation. (Talent et al. 1983), which further reduced the number of homing females the following spring. Assuming that nesting success has declined in recent times because of man-induced change (Miller 1971), it seems likely that a higher proportion of the Mallard population breeding on the prairies is pioneering than in former periods.

Water conditions influence Mallard nesting activity through their effect on the abundance of food resources sought by females preparing to nest. Seasonal wetlands are a major foraging habitat of Mallards (Dwyer et al. 1979), and, with most being in a drawdown condition during drought, availability of food declines sharply. Laying females rely upon aquatic invertebrates to supply protein for producing a clutch of viable eggs (Swanson et al. 1979, Krapu 1981). Food quality and abundance influence both egg production and egg viability (Krapu 1979). When high-quality food is abundant, females are capable of producing several clutches. Under conditions of low food availability, however, the incidence of renesting decreases.

Mallards on the MSA in 1977 were restricted to foraging in deep ponds and lakes with a limited invertebrate food base. Midge larvae, an important Mallard food source (Perret 1962), were present in low densities in the basins holding water. For example, midge densities in a random sample of 16 wetlands on the MSA averaged 673 larvae $/ \mathrm{m}^{2}$ during May and June 1977 (Talent et al. 1982). Comparable data are lacking for 1976 but, in another study, habitat conditions were considered favorable for waterfowl production when midge larvae density averaged $10,800 / \mathrm{m}^{2}$ (McKnight and Low 1969), 16 times greater than recorded on the MSA in 1977. Wetland conditions on the ISA were generally better than on the MSA in 1977 due to more carry-over water from the previous fall. Samples taken from shallow sites in two large marshes in the vicinity of the ISA in 1977 averaged 6,674 midge larvae $/ \mathrm{m}^{2}$ (Talent pers. comm.). A total of $34 \%$ of the Mallard nests found on the ISA in 1977 where within $2.4 \mathrm{~km}$ of a 162-ha shallow marsh where midge larvae density averaged $9,584 / \mathrm{m}^{2}$. The MSA did not include marshes with comparable midge-larvae densities in 1977. Moreover, a general lack of runoff during April and May prevented access to the earthworm, a terrestrial invertebrate that is a major food in the diet of laying females (Swanson et al. 1979).

Home-range size varies with breeding requisites and population density. Prairie-nesting Mallards have relatively large home ranges, averaging several hundred hectares in size (Dzubin 1955, Dwyer et al. 1979, this study). The home ranges of numerous pairs may overlap, but the utilized territory is defended from neighboring pairs during the breeding season (Titman 1983). The male's defensive behavior allows the female to forage undisturbed, thereby maximizing her foraging success and nesting capability (Krapu 1981). The actual spacing of pairs is strongly influenced by foraging conditions. In 1977, with a general lack of high- 


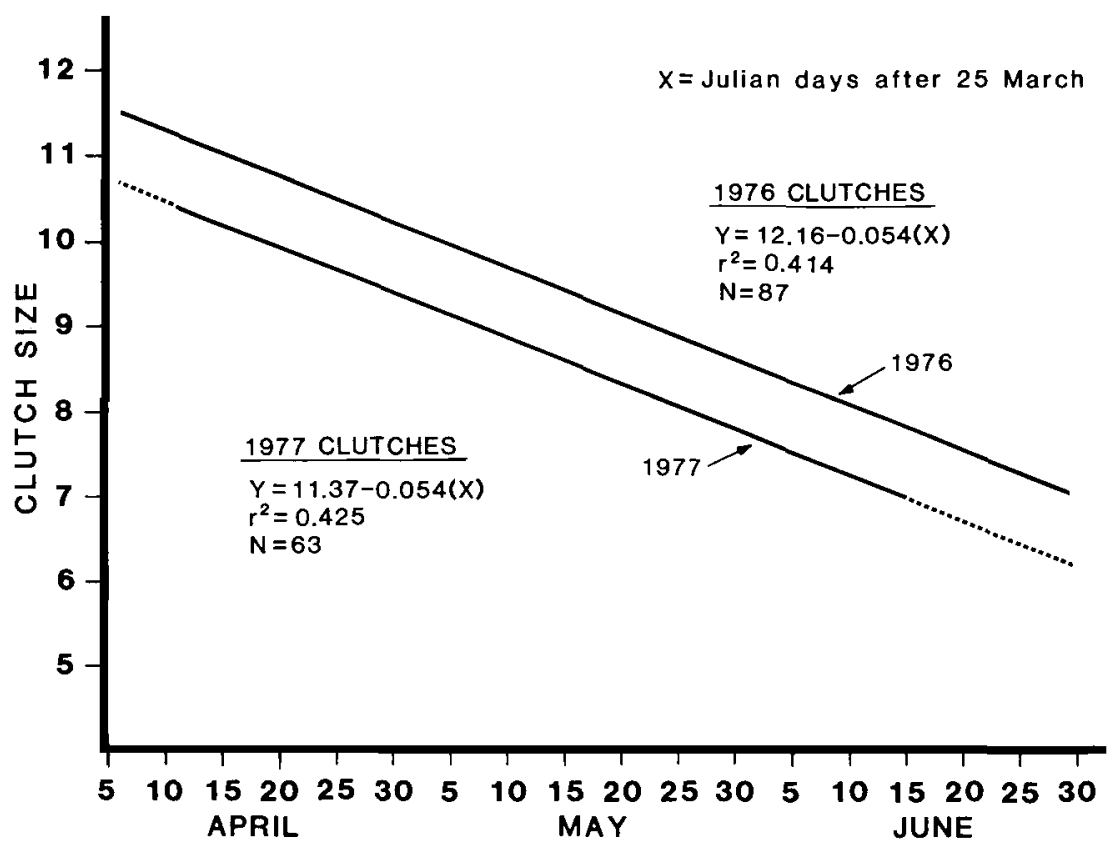

Fig. 6. Average clutch size of Mallards in relation to date of nest initiation on the Interstate Study Area during 1976 and 1977.

quality foraging sites on the MSA, utilized territories were widely spaced. Under conditions in which food abundance varies widely between wetlands, pair distribution will vary accordingly. On a study area in northwestern North Dakota, Duebbert et al. (in press) found that the density of Mallard pairs averaged 5.9 pairs/ha in seasonal wetlands and 1 pair/ha on semipermanent wetlands. Their findings indicated that Mallards were tolerant to crowding at nest sites when other requisites were available. It has been shown that under conditions of high pair density, territory size is compressed (see Titman 1983). The presence of some wetlands with relatively abundant food resources and large home-range sizes probably accounts for the success of Mallard pairs in producing initial clutches on the ISA in 1977. Foraging sites with comparable food resources were not available on the MSA.

The need for invertebrate foods to meet breeding requirements increases the species' vulnerability to drought. At the onset of the nesting season, lipid reserves carried to the breeding grounds supply part of the birds' energy requirements and allow females partially to overcome periods of food scarcity (Krapu 1981). Our findings from the MSA suggest, however, that, when most wetlands are dry and only the most permanent ponds hold water, few pairs breed. As stored lipids are usually depleted by the time renesting attempts begin. (Krapu 1981), renesting activity is particularly susceptible to drought conditions. The duration of nesting activity is strongly influenced by water conditions because of the need of renesting females for an abundant food source. In other studies, a hatching interval of up to 104 days (1955) under favorable water conditions was reported near Kindersley in west central Saskatchewan (Gollop and Fyfe 1956), but it averaged only 66 days (1956-1959) under drought conditions (Dzubin and Gollop 1972).

In the semiarid prairie pothole environment, marked changes in water conditions can occur within a single season, causing major changes in food availability (Swanson et al. 1974, Swanson et al. 1979). Pairs adjust spacially to changing water conditions as they compete for the necessary requisites for breeding (Dzubin 1969). As habitat deteriorates because of drought, aggression intensifies, forcing an increasing number of pairs into suboptimal habitat or emigration and the probable abandonment of nesting for the year. The level of interaction among pairs can be expected to vary widely 
among years, primarily because of the instability of water conditions and, ultimately, the food supply.

Clutches laid by wild Mallards generally exhibit a seasonal decline (Klomp 1970, Dzubin and Gollop 1972: 126, Krapu 1981, present study). It has been proposed that some ultimate factor, such as the average availability of food for the young and female, rather than proximate reasons, such as changes in food supply, younger birds nesting later, and population density, is responsible for the seasonal decline (Batt and Prince 1979). The annual variation in mean clutch size between 1976 and 1977 presumably was caused by proximate factors. The later nesting of females in 1977 and their smaller clutches potentially could have been due to a higher proportion of yearlings in the population during that year. Previous studies have shown yearling females tend to nest later and lay fewer eggs (Coulter and Miller 1968, Krapu and Doty 1979). Circumstantial evidence, however, tends to cast doubt on this hypothesis. This conclusion is based on knowledge that similar numbers of successful nests were present on the study area in 1975 and 1976 (Klett unpubl. data), so comparable numbers of females returning as adults would have been expected in 1976 and 1977. A similar scale of initial nesting attempts during the $2 \mathrm{yr}$ lends support to this assumption. The delay in nesting during 1977 contributed to the decline in mean clutch size. A reduction in nutrient reserves concomitant with a delay in nesting during 1977 may have contributed to the decline in clutch size. The prairie drought of 1977 has been reported to be responsible for reduced clutch sizes among arctic-nesting Lesser Snow Geese (Chen caerulescens caerulescens) (Davies and Cooke 1983). In that study, reduced nutrient reserves resulting from diminished availability of high-quality food during migration was proposed as a major factor contributing to smaller clutch sizes. Differences in distribution and abundance of food resources have previously been identified as a proximate cause of annual variation in clutch size among certain species of waterfowl nesting at Lake Mývatn in Iceland (Bengtson 1971).

In summary, the Mallard has several attributes well suited for maximizing reproductive output under variable water conditions in the glaciated prairie region of North America. These attributes include being philopatric to sites where nesting was previously successful; selecting "safe" nesting sites where available, such as islands; pioneering new areas when nesting in old areas was unsuccessful; occupying a large home range that allows food and nesting cover to be widely spaced; tolerating crowding when habitat conditions are favorable at feeding and nesting sites; having the capacity to lay large initial clutches subsidized by lipid reserves carried to the nesting grounds; and having the ability to renest several times, if necessary, when water conditions are favorable. To compensate for occasional prolonged periods of drought or other adverse conditions, the birds are long-lived (Johnsgard 1968). By not breeding when conditions are unfavorable, the birds enhance their survival and their probability of reproducing later when habitat conditions improve. They are capable of surviving through several years of widespread drought or other causes of nesting failure and still returning to breed when conditions improve. These attributes explain the causes of the widespread distribution and abundance of the Mallard in the midcontinent region before intensive agricultural development and the mechanisms whereby this species has occupied and flourished in a wide array of habitats extending across most of temperate North America and Eurasia.

\section{ACKNOWLEDGMENTS}

We thank private landowners and the North Dakota State Highway Department for the opportunity to conduct this study on the Medina and I-94 rightof-way study areas, respectively, and Sharon Rhode of the Office of Migratory Bird Management of the U.S. Fish and Wildlife Service for providing data on Mallard pair and pond densities from the annual pair and pond survey. We are grateful to B. D. J. Batt, J. L. Eldridge, H. J. Frith, D. H. Johnson, A. B. Sargeant, and $R$. D. Titman for critically reviewing the manuscript. Thanks are also due to T. J. Dwyer, E. L. Ferguson, C. W. Shaiffer, and other staff of the Northern Prairie Wildlife Research Center for their assistance during the study. The figures were drawn by M. I. Meyer and C. W. Shaiffer.

\section{Literature Cited}

BAILEY, R. O. 1979. Wild Mallard stocking in a large marsh habitat. Can. Field-Natur. 93: 55-62.

BAtT, B. D. J., \& H. H. Prince. 1979. Laying dates, clutch size and egg weight of captive Mallards. Condor 81: 35-41.

Bellrose, F. C. 1980. Ducks, geese, and swans of 
North America. Harrisburg, Pennsylvania, Stackpole Books.

BENGTSON, S.-A. 1971. Variations in clutch-size in ducks in relation to the food supply. Ibis 113 : 523-526.

Calverley, B. K., \& D. A. BoAG. 1977. Reproductive potential in parkland- and arctic-nesting populations of Mallards and Pintails (Anatidae). Can. J. Zool. 55: 1242-1251.

Clayton, L. 1967. Stagnant-glacier features of the Missouri Coteau in North Dakota. Pp. 25-46 in Glacial geology of the Missouri Coteau and adjacent areas (L. Clayton and T. Freers, Eds.). North Dakota Geol. Surv. Misc. Ser. 30.

Coulter, M. W., \& W. R. Miller. 1968. Nesting biology of Black Ducks and Mallards in northern New England. Vermont Fish \& Game Dept. Bull. 68-2.

Cowardin, L. M., \& D. H. Johnson. 1979. Mathematics and Mallard management. J. Wildl. Mgmt. 43: $18-35$

CRISSEY, W. F. 1969. Prairie potholes from a continental view point. Pp. 161-171 in Saskatoon wetlands seminar. Can. Wildl. Serv. Rept. Ser. 6.

Davies, J. C., \& F. COOKE. 1983. Annual nesting productivity in Snow Geese: prairie droughts and arctic springs. J. Wildl. Mgmt. 47: 291-296.

Derksen, D. V., \& W. D. Eldridge. 1980. Droughtdisplacement of Pintails to the arctic coastal plain, Alaska. J. Wildl. Mgmt. 44: 224-229.

DerRickson, S. R. 1978. The mobility of breeding Pintails. Auk 95: 104-114.

Doty, H. A., \& F. B. LeE. 1974. Homing to nest baskets by wild female Mallards. J. Wildl. Mgmt. 38: 714-719.

Drewien, R. C., \& L. F. Fredrickson. 1970. High density Mallard nesting on a South Dakota island. Wilson Bull. 82: 95-96.

DUEbBert, H. F., J. T. LOKEMOEN, AND D. E. SHARP. In press. Concentrated nesting of Mallards and Gadwalls on Miller Lake Island, North Dakota. J. Wildl. Mgmt.

DWYER, T. J. 1972. An adjustable radio-package for ducks. Bird-Banding 43: 282-284.

_-1974. Social behavior of breeding Gadwalls in North Dakota. Auk 91: 375-386.

- G. L. KRAPU, \& D. M. JANKE. 1979. Use of prairie pothole habitat by breeding Mallards. J. Wildl. Mgmt. 43: 526-531.

DzubiN, A. 1955. Some evidences of home range in waterfowl. Trans. North Amer. Wildl. Conf. 20: 278-298

- 1969. Comments on carrying capacity of small ponds for ducks and possible effects of density on Mallard production. Pp. 138-160 in Saskatoon wetlands seminar. Can. Wildl. Serv. Rept. Ser. 6.

—_, \& J. B. Gollop. 1972. Aspects of Mallard breeding ecology in Canadian parkland and grassland. Pp. 113-152 in Population ecology of migratory birds: a symposium. U.S. Fish Wildl. Serv. Wildl. Res. Rept. 2

EISENLOHR, W. S., JR. 1969. Hydrology of small water areas in the prairie pothole region. Pp. 35-39 in Saskatoon wetlands seminar. Can. Wildl. Serv. Rept. Ser. 6.

—, \& C. E. SLOAN. 1968. Generalized hydrology of prairie potholes on the Coteau du Missouri, North Dakota. U.S. Geol. Surv. Circ. 558.

Frith, H. J. 1967. Waterfowl in Australia. Honolulu, Hawaii, East-West Center Press.

Giroux, J.-F. 1981. Ducks nesting on artificial islands during drought. J. Wildl. Mgmt. 45: 783786.

GOLLOP, J. B., \& R. W. FyFE. 1956. Waterfowl breeding ground survey in Saskatchewan, 1955, Kindersley Study Area. Pp. 73-76 in Waterfowl populations and breeding conditions-summer 1955. U.S. Fish Wildl. Serv. Spec. Sci. Rept. Wildl. 30.

HigGiNs, K. F., L. M. KIRSCH, \& I. J. BALL, JR. 1969. A cable-chain device for locating duck nests. J. Wildl. Mgmt. 33: 1009-1011.

JOHNSGARD, P. A. 1968. Waterfowl: their biology and natural history. Lincoln, Nebraska, Univ. Nebraska Press.

JoHnson, D. H., \& A. B. SARGEANT. 1977. Impact of red fox predation on the sex ratio of prairie Mallards. U.S. Fish Wildl. Serv. Wildl. Res. Rept. 6.

KLetT, A. T., \& D. H. Johnson. 1982. Variability in nest survival rates and implications to nesting studies. Auk 99: 77-87

KLOMP, H. 1970. The determination of clutch-size in birds. A review. Ardea 58: 1-124.

Krapu, G. L. 1974. Feeding ecology of Pintail hens during reproduction. Auk 91: 278-290.

- 1979. Nutrition of female dabbling ducks during reproduction. Pp. 59-70 in Waterfowl and wetlands-an integrated review (T. A. Bookhout, Ed.). North Central Section of The Wildlife Society.

- 1981. The role of nutrient reserves in Mallard reproduction. Auk 98: 29-38.

- \& H. A. DoTY. 1979. Age-related aspects of Mallard reproduction. Wildfowl 30: 35-39.

LeE, F. B., \& A. D. KRuse. 1973. High survival and homing rate of hand-reared wild-strain Mallards. J. Wildl. Mgmt. 37: 154-159.

Martin, F. W., R. S. Pospahala, \& J. D. Nichols. 1979. Assessment and population management of North American migratory birds. Pp. 187-239 in Environmental biomonitoring, assessment, prediction, and management-certain case studies and related quantitative issues (J. Cairns, Jr., G. P. Patil, and W. E. Waters, Eds.). Fairland, Maryland, International Co-operative Publishing House.

Mayfield, H. F. 1961. Nesting success calculated from exposure. Wilson Bull. 73: 255-261. 
1975. Suggestions for calculating nest success. Wilson Bull. 87: 456-466.

MCKNIGHT, D. E., \& J. B. Low. 1969. Factors affecting waterfowl production on a spring-fed salt marsh in Utah. Trans. North Amer. Wildl. Nat. Resources Conf. 34: 307-314.

Miller, H. W. 1971. Relationships of duck nesting success to land use in North and South Dakota. Pp. 133-140 in Trans. 10th Congress Intern. Union Game Biol., Paris, France.

Odum, E. P., \& E. J. KuenzleR. 1955. Measurement of territory and home range size in birds. Auk 72: $128-137$.

OETrING, R. B., \& J. F. CASSEL. 1971. Waterfowl nesting on interstate highway right-of-way in North Dakota. J. Wildl. Mgmt. 35: 774-781.

Perret, N. G. 1962. The spring and summer foods of the common Mallard (Anas platyrhynchos platyrhynchos L.) in south central Manitoba. Unpublished M.S. thesis, Vancouver, British Columbia, Univ. British Columbia.

SELlers, R. A. 1973. Mallard releases in understocked prairie pothole habitat. J. Wildl. Mgmt. 37: 10-22.

SLOAN, C. E. 1972. Ground-water hydrology of prairie potholes in North Dakota. U.S. Geol. Surv. Prof. Pap. 585-C.

Smith, A. G. 1969. Waterfowl-habitat relationships on the Lousana, Alberta, Waterfowl Study Area. Pp. 116-122 in Saskatoon wetlands seminar. Can. Wildl. Serv. Rept. Ser. 6.

- 1971. Ecological factors affecting waterfowl production in the Alberta parklands. U.S. Fish Wildl. Serv. Resource Publ. 98.

SmITH, R. I. 1968. The social aspects of reproductive behavior in the Pintail. Auk 85: 381-396.

- 1970. Response of Pintail breeding populations to drought. J. Wildl. Mgmt. 34: 943-946.

Sowls, L. K. 1955. Prairie ducks. Harrisburg, Pennsylvania, Stackpole Co.

Stewart, R. E., \& H. A. Kantrud. 1971. Classifica- tion of natural ponds and lakes in the glaciated prairie region. U.S. Fish Wildl. Serv. Resource Publ. 92.

, \& - 1972. Population estimates of breeding birds in North Dakota. Auk 89: 766788 .

— \& $\&$. 1973. Ecological distribution of breeding waterfowl populations in North Dakota. J. Wildl. Mgmt. 37: 39-50.

—_ \& 1974. Breeding waterfowl populations in the prairie pothole region of North Dakota. Condor 76: 70-79.

Swanson, G. A., \& M. I. Meyer. 1977. Impact of fluctuating water levels on feeding ecology of breeding Blue-winged Teal. J. Wildl. Mgmt. 41: $426-433$.

— - \& J. R. SERIE. 1974. Feeding ecology of breeding Blue-winged Teals. J. Wildl. Mgmt. 38: 396-407.

G. L. KRAPU, \& J. R. SERIE. 1979. Foods of laying female dabbling ducks on the breeding grounds. Pp. 47-57 in Waterfowl and wetlandsan integrated review (T. A. Bookhout, Ed.). North Central Section of The Wildlife Society.

TAlent, L. G., G. L. Krapu, \& R. L. Jarvis. 1982. Habitat use by Mallard broods in south central North Dakota. J. Wildl. Mgmt. 46: 629-635.

—, R. L. JARVIS, \& G. L. KRAPU. 1983. Survival of Mallard broods in south central North Dakota. Condor 85: 74-78.

Titman, R. D. 1983. Spacing and three-bird flights of Mallards breeding in pothole habitat. Can. J. Zool. 61: 839-847.

WELLER, M. W. 1956. A simple field candler for waterfowl eggs. J. Wildl. Mgmt. 20: 111-113.

- \& C. S. SPATChER. 1965. Role of habitat in the distribution and abundance of marsh birds. Iowa Agric. Home Econ. Exp. Sta. Spec. Rept. 43.

Winters, H. A. 1963. Geology and ground water resources of Stutsman County, North Dakota. North Dakota Geol. Surv. Bull. 41. 